\title{
TEHRAN UNIVERSITY NUCLEAR CENTRE RADIOCARBON DATES II
}

\author{
CHARLES BOVINGTON, AZIZEH MAHDAVI, \\ and ROGHIYEH MASOUMI
}

Tehran University Nuclear Centre, P.O.B. 2989, Tehran, Iran

Ages reported in this date list are calculated using the Libby half life of $5568 \pm 30$ years with 1950 as the standard year of reference; results are quoted in years B.P. and on the A.D./B.C. time scale.

Since much of our work involves correlations with material in an historical context in Mesopotamia it is important that the reader considers the implications of using 5730 years as the half-life of $\mathrm{C}^{14}$ and the corrections proposed by Ralph and Michael (1969) and others to allow for discrepancies between radiocarbon ages and calendrical ages.

All samples were examined for plant rootlets and other foreign matter, treated with $3 \mathrm{M} \mathrm{HCl}, 3 \mathrm{M} \mathrm{NaOH}$, and de-ionized water. The contemporary reference used is 0.95 of the specific activity of NBS oxalic acid.

\section{ACKNOWLEDGMENTS}

Samples were submitted and evaluated by J. R. Dessaunettes, FAO Expert UNDP, R. Dyson, Univ. Pennsylvania, M. Tosi, ISMEO Rome, W. Sumner, Ohio State Univ., Henry T. Wright, Univ. Michigan, C. C. Lamberg-Karlovsky, Harvard Univ., D. Stronach, Brit. Inst. Persian Studies, G. Dolfus, CNRS Paris, J. Dehayes and J. Perrot, Delegation Archeol. Francais en Iran. This work was carried out during the secondment of C.H.B. to TUNC by the British Government Overseas Development Administration under CENTO Technical Assistance agreement. The assistance of K. Kamali is gratefully acknowledged.

\section{SAMPLE DESGRIPTIONS \\ I. GEOLOGICAL SAMPLES (IRAN)}

\section{Nasserabad soil series}

Nasserabad is N of Ghazvin-Rasht, ca. 15km from Ghazvin. Samples are calcium carbonate concretions, from accumulation horizon $\mathrm{BCa}$ of a Calcic Xerosol (FAO) or Calciorthid (USDA). Depth: $40 \mathrm{~cm}$ to $80 \mathrm{~cm}$. Expected age: latter pluvial, ca. 10,000 B.P. Samples are in pairs, calcium carbonate concretions and surrounding soil. Samples subm. by J. R. Dessaunettes, FAO, UNDP.

\section{TUNC-14. Calcium carbonate concretions}

$$
\begin{array}{r}
10,080 \pm 310 \\
9925 \pm 380
\end{array}
$$

TUNC-15. Surrounding soil carbonate

\section{Sarvestan}

Sarvestan Profile 19 is $80 \mathrm{~km}$ SW of Shiraz. Calcium carbonate concretion from accumulation horizon BCa of a Luvix Xerosol (FAO) or Haplargid (USDA). Depth: 65 to $85 \mathrm{~cm}$. Expected age: earlier than TUNC-14-15, possibly from paleopetrocalcic horizon. 
TUNC-16. Concretion

TUNC-17. Soil carbonate

$14,690 \pm 360$

\section{Ghazvin}

Ghazvin Profile 411 is $40 \mathrm{~km}$ SW of Ghazvin. Calcium carbonate concretion from accumulation horizon BCa of a Calcic Xerosol. Depth: 60 to $90 \mathrm{~cm}$. Expected age: similar to TUNC-14-15.

\section{TUNC-18. Concretion}

$$
10,340 \pm 385
$$

TUNC-19. Soil carbonate

$$
10,275 \pm 220
$$

Comment: results similar to ones obtained in North Africa (Tessler, 1970). Sarvestan Profile reveals that paleoargillic horizon is older and shows another type of evolution. Similar ages obtained for concretions and soil carbonate suggest a common origin.

\section{Tepe Hissar}

$$
\text { II. ARCHAEOLOGIC SAMPLES }
$$

\section{TUNC-20. Charcoal}

$$
3483 \pm 63
$$

Tepe Hissar, Damghan, (36 $06^{\circ}$ N Lat, $54^{\circ} 22^{\prime}$ E Long). Sample coll. and subm. 1971 by R. Dyson, Univ. Penn. Site excavated 1937 by E. Schmidt.

Sample from ash lens on top of wall stub projecting W side Sq. CH 86. Just E of and stratigraphically lower than Burial 9. Ref.: E. Schmidt, 1937, Fig. 101, Period III. Sample dates late occupation of III C period. Comment: date, when corrected, suggests a terminal date for Hissar III C of ca. 1800 в.c. Despite elapsed period since original excavation, sample seems good. Wall stub $>1 \mathrm{~m}$ high shows no signs of animal activity. Lens protected by in situ melted down mud brick.

\section{Shahr-i-Sokhta series}

Shahr-i-Sokhta $\left(30^{\circ} 44^{\prime} \mathrm{N}\right.$ Lat, $61^{\circ} 30^{\prime} \mathrm{E}$ Long), is in Sistan Prov. Samples coll. and subm. 1970 by M. Tosi, ISMEO, Rome (Tosi, 1969). Samples from Tapa Rud-i Buyakan 2 are related to Shahr-i-Sokhta III period, $29 \mathrm{~m}$ SE of Shahr-i-Sokhta, the main III millennium site of the region.

TUNC-21. Charcoal, TRB2 F49

$4065 \pm 65$

Carboni da Piano calcenato.

TUNC-22. Charcoal, TRB2 DF

Carboni Sparsi Angalo NW sec.

TUNC-23. Charcoal, TR2 DA

From jar under Kiln 2.
2115 B.C.

$3829 \pm 61$ 1879 B.C.

$4082 \pm 66$ 2132 B.c. 
TUNC-24. Charcoal, TRB2 DF, E side $3943 \pm 70$

\section{TUNC-24. Charcoal, TRB2 DF, E side}

TUNC-25. Charcoal, TRB2 F4 1993 B.C.

Carboni da Atrio. $4278 \pm 58$

TUNC-26. Charcoal, TRB2 DF 2328 B.C.

Group of ashes from $\mathrm{E}$ side.

TUNC-27. Charcoal, TRB2 F4 $4115 \pm 72$ 2165 B.c.

Carboni E argilla Bruciati.

Comment: corrected dates suggest time span of 2600 to 2350 в.c. consistent with typologic parallels with ED Mesopotamia and Tepe Yaya.

\section{Tall-i-Malyan series}

Tall-i-Malyan, Fars prov. ( $30^{\circ} \mathrm{W}$ Lat, $52^{\circ} \mathrm{E}$ Long) $46 \mathrm{~m} \mathrm{~N}$ of Shiraz in Kur River basin. Site is a large mound ca. $300 \mathrm{~h}$ probably occupied during 3rd and into 2nd millennium в.c. (Sumner, 1972). Samples coll. and subm. 1971 by W. Sumner, Univ. Penn. and Ohio State Univ.

\section{Kaftari Period}

\section{TUNC-28.}

$$
3510 \pm 63
$$

Charcoal above building Level I, Kaftari, Operation A, Lot 3, Strat. 3, Sample 82.

\section{TUNC-29.}

Charcoal above building Level I, Kaftari, Operation A, Lot 3, Strat. 3, Sample 82.

\section{TUNC-30.}

Charcoal above building Level I, Kaftari, Operation A, Lot 3, Strat. 3, Sample 59.

\section{Banash Period}

TUNC-31.

Charcoal assoc. with building Level IV, Banash period, Operation B, Lot 63, Sample 227.

Comment: TUNC-28-30 assign latest levels of Kaftari period to early 2nd millennium and TUNC-31 suggests Banash period may be as early as late 4 th and early 3 rd millennium.

\section{Sharafabad series}

Sharafabad is near Desful (32 $23^{\prime}$ N Lat, $48^{\circ} 28^{\prime}$ E Long), Khuzistan prov. Samples coll. and subm. 1970 by Henry T. Wright, Mus. Anthropol., Univ. Michigan. 


\section{Uruk Period}

TUNC-32.

$4832 \pm 55$

Carbon from Bevel Rim Bow pit.

TUNC-33.

$4331 \pm 50$

2381 B.C.

Carbon from Bevel Rim Bowl pit, Lot 13.

Middle Elamite Period

TUNC-34.

$3172 \pm 125$

1222 B.C.

Carbon from construction Phase III B floor.

$3200 \pm 138$

TUNC-35.

1250 B.C.

Ash carbon from construction Phase III floor.

Comment: TUNC-34-35 somewhat undersized. If they are corrected for half-life and estimate of calendric age based on tree-ring measurements would fit with pottery evidence ca. 1600 B.c. TUNC-32-33 somewhat later than expected.

\section{Tepe Yaya series}

Tepe Yaya is near Baft $\left(29^{\circ} 12^{\prime} \mathrm{W}\right.$ Lat, $56^{\circ} 36^{\prime} \mathrm{E}$ Long), Kerman. Excavated and subm. by C. C. Lamberg-Karlovsky, Peabody Mus., Harvard Univ. Samples date Proto-Elamite, Iron age, and Patho-Sasanian settlements (Lamberg-Karlovsky, 1970; 1972).

\section{TUNC-37.}

$4725 \pm 116$

Charcoal B, Stratum 1, between floors, Period IV C.

TUNC-38.

$4254 \pm 85$

2304 B.C.

Charcoal XC, Test Trench 2, Stratum 8N, N Feature 28, beneath Stratum 7 and at level of Stratum 8, Period IV C.

TUNC-39.

$3859 \pm 71$

1909 B.c.

Charcoal XB, Test Trench 2, Stratum 6b, E of Feature 36, Period IV B.

TUNC-40.

$2415 \pm 65$

465 B.C.

Charcoal A, Stratum 34, grain bin of Building A, Stratum 29 in fill, Period III.

TUNC-41.

$1943 \pm 49$

Charcoal bulk AWI/AWWI, Stratum 1, NW corner assoc. with burnt floor, Period I.

General Comment: implications of tree-ring corrections considered, these results, placing YYIV C contemporary with late Uruk (Jemdat Nasr) 
and Sahr-i-Sokhta I seem sensible. Similarly evidence is overwhelming for placing YY IV B with ED I/II and Shahr-i-Sokhta III and the "corrected" radiocarbon dates would again fit the typologic parallels.

\section{Tureng Tepe series}

Tureng Tepe is near Gorgan (36 $50^{\prime} \mathrm{N}$ Lat, 54 $24^{\circ} \mathrm{E}$ Long). Sample coll. and subm. 1972 by J. Dehayes, Delegation Archaeol. Francais en Iran. Sample from Hissar III C level (Tureng Tepe III C) (Deshayes 1969; 1972).

TUNC-42.

$3517 \pm 70$

1567 B.C.

Charcoal from Tureng Tepe III C level, assoc. with typical pottery of Hissar III C type destruction level of large building under foundations of an Achemenian Terrace.

Comment: date comparable to TUNC-20: $3483 \pm 63$, and confirms a probably terminal date for Eastern Gray ware on Gurgan culture (Hissar III C, Tureng Tepe III G) of ca. 1800 to 1850 B.C.

\section{Susa series}

Samples from Tepe Djafarabad and Susa, Khuzestan $\left(32^{\circ} 11^{\prime} \mathrm{N}\right.$ Lat, $48^{\circ} 27^{\prime}$ E Long). Coll. and subm. 1970-71 by G. Dolfus, CNRS and J. Perrot and A. Lebrun, Delegation archaeol. Francaise en Iran. TUNC-43, -44, -46, -48, -50 and -58 from levels containing Susa I pottery, a culture dated to 1st half 4 th millennium, TUNG-59 from Uruk period (Le Breton, 1957; Perrot, 1971; Dolfus, 1972).

\section{Djafforabad series}

TUNC-43.

$4966 \pm 84$

Charcoal, Cat. No. 1415, Sq. G8, Bed g, Level 3. 3016 B.C.

TUNC-44.

$5096 \pm 121$

Charcoal, Cat. No. 1264, Sq. G9, Bed g, Level 3.

3146 B.c.

TUNC-46.

$5141 \pm 122$

Charcoal, Cat. No. 1240, Sq. H9, Level 3.

3191 B.C.

TUNC-48.

$5133 \pm 94$ 3083 B.C.

\section{Susa series}

Charcoal, Cat. No. 1166, Sq. G7, Log 719, Level 3.

TUNC-58.

$5665 \pm 121$

Charcoal, Acropole II, Loc. 5.3.9.

TUNC-59.

3715 B.C.

Charcoal, S ACR 1780 H5 URUK.

$4646 \pm 93$

2676 B.C.

Comment: TUNC-43, -44, -46, -48, -58 comparable to TUNG-3-6 
and P-912, 5062, 5116, 5246, 5238, 5428 yr B.P., respectively. TUNC-59, when converted to long half and life and corrected according to Ralph and Michael, agree well with reasonable estimate of probable calendric age.

\section{Shahr-I-Qumis series}

Shahr-I-Qumis is $34 \mathrm{~km} \mathrm{~W}$ of Damghan, $4 \mathrm{~km} \mathrm{~S}$ of Teheran-Meshad Rd. (54 $4^{\circ} 7^{\prime} \mathrm{N} \mathrm{Lat}, 35^{\circ} 55^{\prime} \mathrm{E}$ Long). Coll. and subm. 1971 by J. Hansman and D. Stronach, Brit. Inst. Persian Studies (Hansman and Stronach 1970; 1972). Main occupation of this settlement within Pathian period was probably during 1 st and 2 nd centuries B.C.

TUNC-51.

$332 \pm 57$

Site 5, Rm. 1. Fragments of wood from between Floors 1 and 2.

TUNC-52.

$1962 \pm 63$

Site 7, Rm. 4. Wooden handle (316).

12 B.c.

TUNC-53.

$1864 \pm 69$

Site 5, Rm. 19. Wood from occupation building (319).

TUNC-54.

Unimpregnated wood (317). Site 7, Rm. 1 .

$1937 \pm 48$

A.D. 13

TUNC-55.

Seeds assoc. with last use of building. Site 5, Rm. 18.

$1844 \pm 47$

A.D. 106

TUNC-56.

$1905 \pm 69$

Burnt hay. Site 2, Rm. 1.

\section{A.D. 45}

\section{TUNC-57.}

$1955 \pm 53$

Re-used lintel. Site 5, Rm. 1.

5 B.C.

Comment: TUNC-51 was clearly contaminated. TUNC-52 and 54, converted to long half-life, would seem to agree well with coin evidence of silver drachmas of early 1st century B.c. (Sinatruces, ca. 80 to 69 B.c. or Phraates III, ca. 69 to 57 B.c.) from Site 7, Rm. 2.

\section{REFERENCES}

Bovington, C. H. and Masoumi, R., 1972, Tehran University Nuclear Centre Radiocarbon date list I: Radiocarbon, v. 14, p. 456-460.

Deshayes, J., 1969: Archaeology, v. 22, no. 1, p. 16-19.

1972, Excavations at Tureng Tepe: Iran, v. 10, p. 178-179.

Dolfus, G., 1971, In excavations a Djaffarabad et a l'Acropole de Suse, de 1969-1971: Cahiers de la Delegation Archeol. Francais en Iran, CNRS (Paris 1971). 
Hansman, J. and Stronach, D., 1970, Excavations at Shahr-i-Qumis, 1967: Royal Asiatic Soc. Jour., p. 47.

1972, Excavations at Shahr-i-Qumis: Iran, v. 10, p. 174.

Lamberg-Karlovsky, C. C., 1970, Excavations at Tepe Yaya, Iran, 1967-1969, progress rept. I: Am. School Prehistoric Res. Bull. 27, Peabody Mus., Harvard Univ., Cambridge, Massachusetts.

1972, Tepe-Yaya 1971, Mesopotamia and the Indo-Iranian Borderlands: Iran, v. 10, p. 89-100.

Le Breton, L., 1957, The early period at Susa, Mesopotamian relations: Iraq, v. 19, pt. 2, p. 79-125.

Perrot, J., 1971, Excavations at Susa and Djaffarabad: Iran, v. 9, p. 178-181.

Ralph, E. K. and Michael, H. N., 1969, Univ. of Pennsylvania radiocarbon dates XII: Radiocarbon, v. 11, p. 469-481.

Schmidt, E., 1937, Excavations at Tepe Hissar, Damgham: Univ. of Pennsylvania pubs., Philadelphia.

Stuckenrath, R., Jr., Coe, W. R., and Ralph, E. K., 1966, Univ. of Pennsylvania radiocarbon dates IX: Radiocarbon, v. 8, p. 348-385.

Sumner, W. M., 1972, Excavations at Tall-i-Malyan: Iran, v. 10, p. 176.

Tessier, F., 1970, Premier datation de concretions calcaires dans le Quaternaire de Dakar, Senegal: Liaison ASEQUA Bull. 26, p. 5-10.

Tosi, M. 1969, Excavations at Shahr-i-Sockta, Sistan: East and West, v. 19, Ist. Italiano Medio ed Estremo Oriente, Rome. 